\title{
Pengaruh Customer Satisfaction dan Religiusitas sebagai Variabel Moderasi Atas Penggunaan Islamic Branding terhadap Purchase Intention
}

\section{Taufiq Risal}

Universitas Potensi Utama

jifarkan@gmail.com

\section{Mirawati \\ Universitas Potensi Utama \\ miraterrible@gmail.com \\ Reza Prabudi \\ Universitas Potensi Utama rezaprabudi@gmail.com}

\begin{abstract}
Abstrak Untuk membangkitkan minat nasabah, Islamic Branding dalam industri perbankan syariah perlu memberikan sejumlah besar manfaat yang dapat diperoleh nasabah, untuk dapat memaksimalkan Customer Satisfaction sehingga dapat menghasilkan Purchase Intention yang tinggi. Tingkat Religiusitas nasabah terbukti turut memegang peranan penting dalam memilih lembaga perbankan yang menggunakan Islamic Branding. Penelitian ini bertujuan untuk mempelajari adalah pengaruh kepribadian Islamic Branding terhadap Purchase Intention menggunakan jasa perbankan syariah dengan Customer Satisfaction sebagai variable intervening dan Tingkat Religiusitas Pelanggan sebagai variable moderator. Prosedur pengambilan sampel dalam penelitian ini adalah teknik non-probability sampling. Metode analisis yang digunakan dalam penelitian ini menggunakan SEM (Structural Equation Modeling) dengan aplikasi PLS (Partial Least Squares). Hasil penelitian ini menunjukkan bahwa Islamic Branding mempunyai pengaruh yang signifikan terhadap Customer Satisfaction, tetapi tidak berpengaruh signifikan terhadap Purchase Intention, dan tidak secara tidak langsung akan tidak signifikan mempengaruhi Customer Satisfaction sebagai variabel intervening. Serta Tingkat Religiusitas sebagai variabel moderator tidak terbukti berpengaruh signifikan atas pengaruh Islamic Branding terhadap Customer Satisfaction dan Purchase Intention nasabah BMT Kampoeng Syariah Medan.
\end{abstract}

Kata Kunci Islamic Branding, Purchase Intention, Customer Satisfaction dan Tingkat Religiusitas

\section{PENDAHULUAN}

Indonesia sebagai negara dengan populasi beragama Islam terbesar di dunia merupakan pasar potensial bagi para produsen yang menyasar pada konsumen muslim. Hasil pra survei yang dilakukan peneliti dengan beberapa mahasiswa calon nasabah pada bulan 
Juni 2018 menunjukkan bahwa banyak mahasiswa sebagai nasabah masih ragu untuk menabung di bank syariah karena kurang mengetahui informasi tentang bank syariah, dan tidak memahami sistem bagi hasil diperbankan syariah. Kondisi ini memberikan gambaran bahwa bank syariah memiliki peluang sangat besar sekaligus tantangan untuk dapat meraih pangsa pasar perbankan nasional di masa mendatang (T Risal \& Alexander, 2019).

Ternyata besarnya populasi ummat Muslim di Indonesia saat ini tidak otomatis menjadikan bank syariah sebagai pemenang pasar. Seperti halnya yang terjadi pada BMT Kampoeng Syariah Medan. Jumlah debitur (nasabah) kredit koperasi simpan pinjam BMT setiap tahunnya terkadang mengalami kenaikan jumlah nasabah dan begitu juga sebaliknya. Pertumbuhannya masih jauh dari yang diharapkan. Ditingkat nasional, menurut OJK, pangsa pasar perbankan syariah masih bertahan di 5,7 persen per Agustus 2018. Oleh karena itu apabila ingin memperbesar pangsa pasar perbankan Syariah maka menjadi suatu keharusan untuk mengkaji kembali faktor-faktor yang mempengaruhi purchase intention, sehingga dapat dijadikan dasar untuk membuat strategi yang dapat meningkatkan Purchase Intention tersebut.

Strategi pemasaran yang dapat dilakukan diantaranya adalah dengan mengedepankan lagi penggunaan simbolisasi Islam dengan mengedepankan keunggulan atas penerapan nilai-nilai syariah sebagai nilai jual utama (foreground) diikuti penggunaan kualitas layanan sebagai syarat wajib (necessary condition) pada background. Dengan ini harus dikedepankan aplikasi nilai-nilai yang benar-benar sesuai syariah pada produk perbankan syariah (Taufiq Risal, 2019b).

Strategi yang banyak dilakukan dengan melihat data tersebut adalah Islamic Branding. Yaitu menggunakan identitas Islam (dengan kata Islam, Syariah, nama-nama Islam, label halal) dalam pemasaran produk. Islamic branding pada perbankan syariah dapat menciptakan persepsi bahwa produk jasa yang ditawarkannya bebas dari unsur- unsur yang dilarang oleh agama, khususnya bagi masyarakat muslim. Hal ini mengindikasikan terdapat pengaruh tingkat religiusitas sebagai mediator terhadap hubungan branding dan purchase intention.

Aspek yang terdapat dalam Brand, ternyata juga merupakan hal yang sangat diperhatikan konsumen muslim, apabila dilakukan branding terhadap konsumen muslim. Ternyata konsumen muslim bisa jadi sangat sensitif terhadap tindakan yang dilakukan oleh produsen maupun oleh negara produsen. Konsumen muslim tidak jarang akan memboikot sebuah produk dari negara tertentu jika negara tersebut dinilai menghina atau melecehkan Islam (Alserhan, 2010). Hal ini menggambarkan bahwa religiusitas berpengaruh besar dalam perilaku konsumsi konsumen berkaitan dengan penggunaan Islamic Branding.

Penelitian terhadap 100 mahasiswa di Pakistan tentang Islamic Branding, menyatakan bahwa religiusitas mempunyai pengaruh terhadap Islamic Branding, walaupun persepsi sebagai variabel moderating lebih berpengaruh terhadap Islamic Branding daripada tingkat religiusitas mereka. Artinya bahwa mahasiswa memilih sebuah produk (Islamic Brand) berdasarkan persepsi mereka terhadap produk tersebut dibandingkan dengan tingkat ketauhidannya (Jumani, Zulfikar Ali; Siddiqui, 2012).

Pada hasil penelitian lain juga terlihat bahwa religiusitas juga mempunyai pengaruh terhadap perilaku konsumsi (makanan, pakaian dan mobil) masyarakat berpenghasilan menengah ke atas di wilayah Shah Alam dan Bangi, Malaysia. Penelitian ini menggunakan variabel religiusitas sebagai variabel moderating untuk memperkuat atau memperlemah hubungan antara faktor-faktor konsumsi (tren, kualitas, merk, dan lainlain) dan perilaku konsumen (Alam \& Sayuti, 2011).

BMT Kampoeng Syariah Medan dalam implementasinya ternyata telah menerapkannya dengan menggunakan Islamic Branding dalam pelayanan jasa perbankan yang 
dilayaninya. Sesuai dengan penelitian-penelitian tentang Islamic Branding dan Religiusitas diatas, maka seharusnya penggunaan Islamic Branding dipadu dengan Tingkat Religiusitas nasabah akan berpengaruh meningkatkan Customer Satisfaction yang pada akhirnya akan meningkatkan Purchase Intention.

Namun dalam penelitian sebelum diperoleh fakta bahwa bila Kualitas Pelayanan yang diberikan ternyata tidak dapat menghasilkan Customer Satisfaction yang memuaskan sesuai harapan nasabah (Risal, 2019a). Kondisi inilah yang diprediksi membuat Purchase Intention nasabah tidak sesuai harapan manajemen BMT.

Penelusuran lebih jauh juga menunjukkan perlunya pembuktian bahwa kepercayaan merek sebagai variabel yang memediasi pengaruh religiusitas terhadap perilaku konsumen, sehingga dirasa perlu untuk mengakaji hubungan kausal antara religiusitas, dengan kepercayaan merek dan perilaku pembelian terutama dalam usaha jasa perbankan Syariah (Rinuastuti et al., 2018).

Maka menarik untuk diteliti, apakah belum maksimalnya Customer Satisfaction dipengaruhi juga oleh penggunaan Islamic Branding? Juga apakah ada pengaruh dari Tingkat Religiusitas nasabah terhadap Purchase Intention layanan jasa perbankan syariah BMT Kampoeng Syariah Medan?

\section{LANDASAN TEORI}

\section{Islamic Branding}

Sebuah produk dapat menarik konsumen jika mempunyai merk (brand). Branding memiliki tempat di benak konsumen, bukan di dunia nyata. Branding bukanlah pertarungan untuk menentukan siapa yang dapat membuat produk lebih baik, akan tetapi siapa yang dapat menciptakan persepsi lebih baik. Islamic Branding dapat dimaknai sebagai penggunaan nama-nama yang berkaitan dengan Islam atau menunjukkan identitas halal untuk sebuah produk. Sebagai contoh: hotel syariah, rumah sakit Islam, Wardah, KFC, dan lain-lain. Islamic branding diklasifikasikan dalam tiga bentuk (Alserhan, 2010): (a) Islamic brand by complience Islamic brand harus menunjukkan dan memiliki daya tarik yang kuat pada konsumen dengan cara patuh dan taat kepada syariah Islam (Jumani, et. al, 2012). Brand yang masuk dalam kategori ini adalah produknya halal, diproduksi oleh negara Islam, dan ditujukan untuk konsumen muslim. (b) Islamic brand by origin. Pengguanaan brand tanpa harus menunjukkan kehalalan produknya karena produk berasal negara asal produk tersebut sudah dikenal sebagai negara Islam. (c) Islamic brand by customer. Branding ini berasal dari negara non muslim tetapi produknya dinikmati oleh konsumen muslim. Branding ini biasanya menyertakan label halal pada produknya agar dapat menarik konsumen muslim.

Islamic brand yang memenuhi ketentuan syariah menjadi merek tersendiri. Hal ini memberikan peluang bagi penjual muslim untuk mempromosikan produknya dan menjunjung tinggi nilai- nilai syariah (Fatema et al., 2013).

\section{Purchase Intention}

Skala yang digunakan untuk mengukur variabel Purchase Intention dalam penelitian ini adalah skala yang dikembangkan oleh Ferdinand (2006), yaitu:

1. Minat transaksional, yaitu kecenderungan seseorang untuk membeli produk.

2. Minat refrensial, yaitu kecenderungan seseorang untuk mereferensikan produk kepada orang lain.

3. Minat preferensial, yaitu minat yang menggambarkan perilaku seseorang yang memiliki prefrensi utama pada produk tersebut. Preferensi ini hanya dapat diganti jika terjadi sesuatu dengan produk prefrensinya. 
4. Minat eksploratif, minat ini menggambarkan perilaku seseorang yang selalu mencari informasi mengenai produk yang diminatinya dan mencari informasi untuk mendukung sifat-sifat positif dari produk tersebut

\section{Customer Satisfaction}

Menurut Tjiptono (2014:368-369) konsep inti mengenai objek pengukuran Customer Satisfaction, antara lain:

1. Kepuasan Pelanggan Keseluruhan (Overall Customer Satisfaction). Ada dua bagian dalam proses pengukurannya. Pertama, mengukur tingkat kepuasan pelanggan terhadap produk atau jasa perusahaan bersangkutan. Kedua, menilai dan membandingkannya dengan tingkat kepuasan pelanggan secara keseluruhan terhadap produk atau jasa pesaing.

2. Kesesuaian harapan (Conformance of Expectation). Dalam konsep ini, kepuasan disimpulkan berdasarkan kesesuaian antara harapan pelanggan dengan kinerja actual produk perusahaan pada sejumlah atribut penting.

3. Minat Pembelian Ulang (Repurchase Intent). Kepuasan pelanggan diukur secara behavioral dengan jalan menanyakan apakah pelanggan akan berbelanja atau menggunakan jasa perusahaan lagi.

4. Kesediaan untuk merekomendasi (Willingness to Recommend) Dalam kasus produk yang pembelian ulangnya relative lama atau bahkan hanya terjadi satu kali pembelian, kesediaan pelanggan untuk merekomendasikan kepada teman atau keluarganya menjadi ukuran yang penting untuk ditindak lanjuti.

\section{Religiusitas}

Tingkat Religiusitas sesorang bagian dari faktor budaya yang berkaitan dengan agama dalam subkultur tersebut dapat dikatakan menjadi salah satu faktor yang mempengaruhi keputusan pembelian konsumen. Terlihat dari ketaatan seseorang kepada Tuhannya bahwa jika keyakinan agamanya baik, tercermin dari perilakunya dengan menjalankan segala sesuatu yang diperintahkan Tuhan dan menjauhi segala yang dilarangnya. (Isa et al., 2020).

Delener (1990) menyatakan bahwa religiusitas adalah salah satu faktor pendorong penting dan dapat berpengaruh terhadap perilaku konsumen (Essoo \& Dibb, 2004). Hal ini didasari atas keputusan konsumen untuk membeli produk tergantung kadar keimanan mereka. Skala yang digunakan untuk mengukur tingkat religiusitas dalam penelitian ini adalah lima dimensi religiusitas muslim (El-Menouar, 2014) sebagai berikut:

1) Basic Religiosity. Dimensi pertama ini berisi semua item kepercayaan agama dan praktik renungan. Ini berarti bahwa keyakinan agama tidak dapat diamati secara independen dari praktik. Keyakinan diikuti oleh minimal praktik keagamaan renungan seperti doa pribadi di luar ritual yang diformalkan. Selain itu, tampaknya beberapa jenis pengalaman keagamaan diperlukan untuk mengkonfirmasi kepercayaan Islam. Keyakinan disertai dengan perasaan mahatawa Allah, yang didukung oleh item "merasakan kehadiran Allah" memuat pada komponen yang sama. Item ini terkait dengan dimensi pengalaman keagamaan secara teoritis; namun jelas itu mengukur aspek yang berbeda dari religiositas Muslim. Dimensi ini disebut religiositas dasar karena merupakan prasyuga untuk dimensi lain. Di sisi lain, dimensi lain tidak dapat diurai darinya. Untuk alasan ini, religiositas dasar harus diletakkan.

2) Central Religious Duties. Dimensi kedua mengekspresikan atas kewajiban utama dalam agama. Hal ini terdiri dari lima pondasi dalam islam dan norma-norma dasar 
tambahan seperti ibadah ritual (shalat), puasa bulan Ramadhan, berhaji ke Makkah, serta aturan dalam makanan dan minuman.

3) Religious Experience. Dimensi ini berhubungan dengan perasaan atau pengalaman keagamaan yang sifatnya responsif seperti perasaan atas kehadiranAllah, perasaan memperoleh berkat dan pahala, serta perasaan memperoleh musibah dan dosa.

4) Religious Knowledge. Dimensi ini berhubungan dengan kemampuan kognisi dalam mengetahui dan memahami ajaran agama dasar, seperti mengetahui rukun iman, rukun islam, mampu membaca alQur'an, serta mengetahui sirah atau kehidupan nabi

5) Orthopraxis. Tingkat yang dimana Islam mengatur kehidupan setiap hari penganutnya diluar daripada ritual keagamaan yang ditetapkan memberikan pengertian yang berbeda-beda tentang konsep keshalihan dalam komunitas muslim. Dalam aspek ini serupa dengan konsep ortodoks dalam ajaran Kristen, dimana dalam islam terdapat penganut ajaran fundamentalis yang memiliki perspektif berbeda dengan ajaran mainstream, hal ini bisa diidentifikasi dengan indikator seperti hubungan antar gender, status keharaman musik, serta cara berpakaian.

\section{METODOLOGI PENELITIAN}

Penelitian ini menggunakan metode kuantitatif, yaitu menguraikan data yang diolah menjadi informasi dan membuktikan teori, sehingga dapat memberikan bahan yang berharga untuk pengambilan keputusan. Dengan menggunakan analisis jalur (path analysis), penelitian ini untuk menguji pengaruh variabel independen yaitu Islamic Branding (X) terhadap variabel dependen yaitu Purchase Intention (Y), melalui variabel intervening yaitu Customer Satifaction (V), dengan variable moderasi yaitu Religiusitas (M). Sumber data berupa sumber data drimer yang diperoleh berdasarkan jawaban kuisioner yang dibagikan kepada nasabah representatif. Penelitian dilakukan dengan menemui dan memberikan kuisioner kepada nasabah BMT secara langsung. Prosedur penarikan sampel dengan teknik sampling non-probabilitas, dengan jumlah sampel yang diambil dalam penelitian ini sebanyak 100 orang.

Variabel dalam penelitian ini diklasifikasikan menjadi 4 variabel yaitu Islamic Branding sebagai variabel independen, Purchase Intention sebagai variable dependen, Customer Satisfaction sebagai variable intervening dan Religiusitas sebagai variabel moderator.

Data analisis dengan menggunakan SEM (Structural Equation Modelling) dengan program PLS (Partial Least Square) yang memberikan gambaran jelas berhubungan antara konstruk penelitian.Pengujian hipotesis mediasi dilakukan dengan uji Sobel (Sobel test). Untuk menguji signifikansi pengaruh tidak langsung, maka kita perlu menghitung nilai t. Nilai t hitung ini dibandingkan dengan nilai t table. Jika nilai t hitung lebih besar dari nilai $t$ tabel maka dapat disimpulkan terjadi pengaruh mediasi. Tahapan penelitian dapat diuraikan sebagai berikut:

- Tahap pertama dilakukan pengumpulan data dengan menyebarkan kuesioner kepada responden nasabah BMT dengan target responden dari penelitian 100 responden.

- Tahap kedua data yang berhasil didapatkan kemudian dieleminasi dengan mengeluarkan indikator-indikator yang tidak valid dan reliabel yaitu memiliki nilai loading factor di bawah 0,50, sebelum diolah menggunakan model penelitian dengan bantuan SmartPLS menggunakan pendekatan SEM-PLS.

- Tahap selanjutnya adalah interpretasi hasil pengolahan statistik sebelum ditarik kesimpulan bagaimana hasil analisis faktor Purchase Intention pada BMT berdasarkan pengaruh variabel Islamic Branding dengan adanya variabel intervening Customer Satisfaction dan variabel Moderator Religiusitas terhadap peningkatan Purchase 
Intention. Untuk melakukan pemrosesan data, pemodelan faktor yang digunakan dapat dilihat pada Gambar 3.1. berikut.

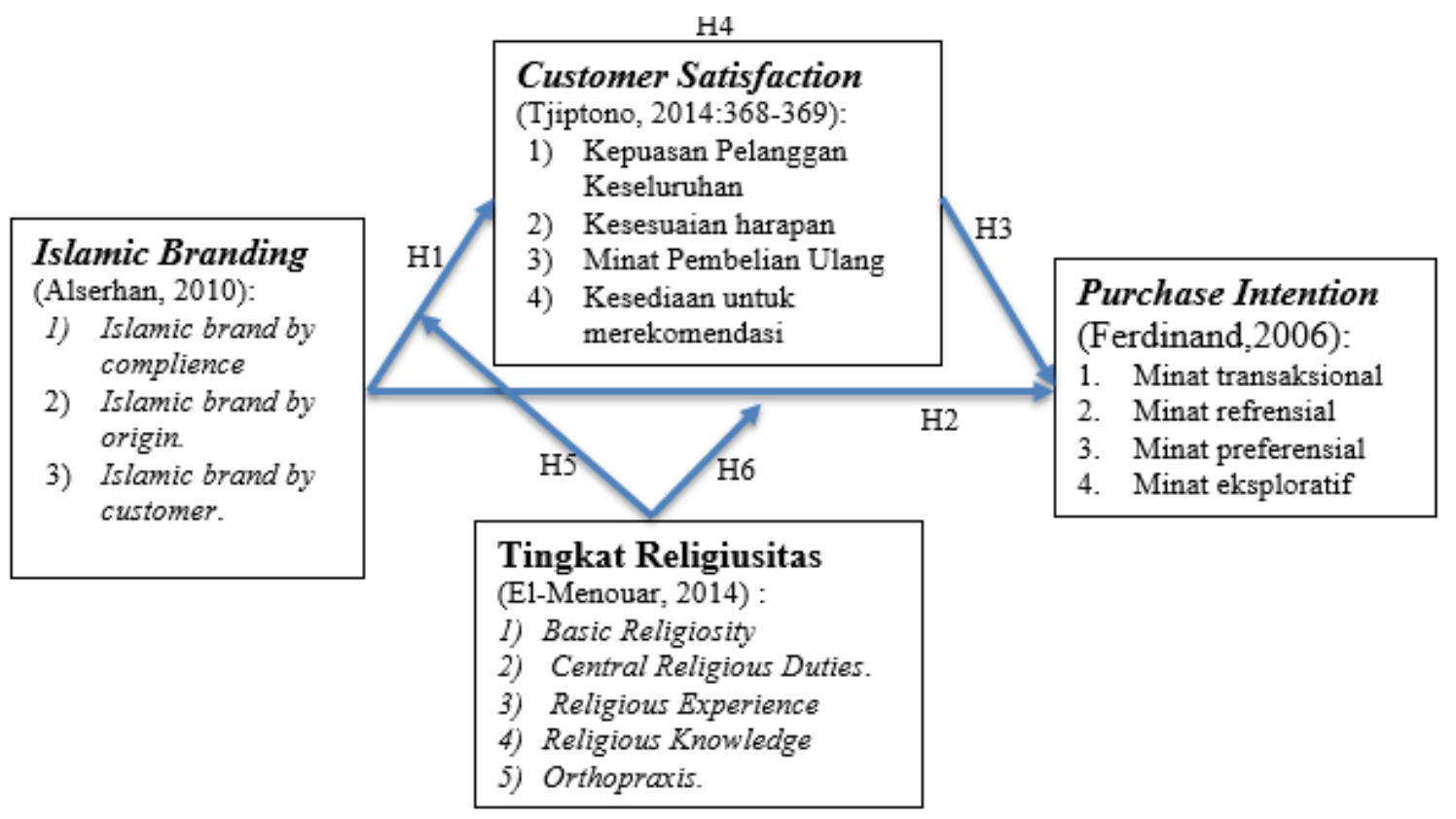

Gambar 3.1. Model penelitian

\section{HASIL PENELITIAN}

Penelitian ini menggunakan SmartPLS untuk mendukung analisis data dan mendapatkan hasil penelitian. Hasil penelitian diharapkan dapat menjawab pertanyaan penelitian untuk memahami implikasi hipotesis. Untuk mendapatkan nilai-nilai uji untuk model struktural (inner model) atau model yang menghubungkan antar konstruk (variabel laten) yang dibangun maka model selanjutnya dianalisis dengan program SmartPLS 3.0 menggunakan fasilitas bootstrapping. Hasil bootsrapping model struktural (inner model) dapat dilihat pada Gambar 4.1.

Dalam PLS pengujian secara statistik setiap hubungan yang dihipotesiskan dilakukan dengan menggunakan simulasi.Pengujian hipotesis dilakukan dengan melihat nilai t, jika $\mathrm{t}$-value lebih besar dibanding t-tabel (alpha 5\% = 1,96) maka hipotesis (Ha) diterima dan H0 ditolak, dan sebaliknya. Pengujian hipotesis dilakukan dengan metode resampling Bootsrap yang dikembangkan oleh Geisser \& Stone. Pengujian hipotesis ini dilihat dari hasil t-value dari struktur hasil uji path dan dibandingkan dengan T-tabel $(1,96)$. 


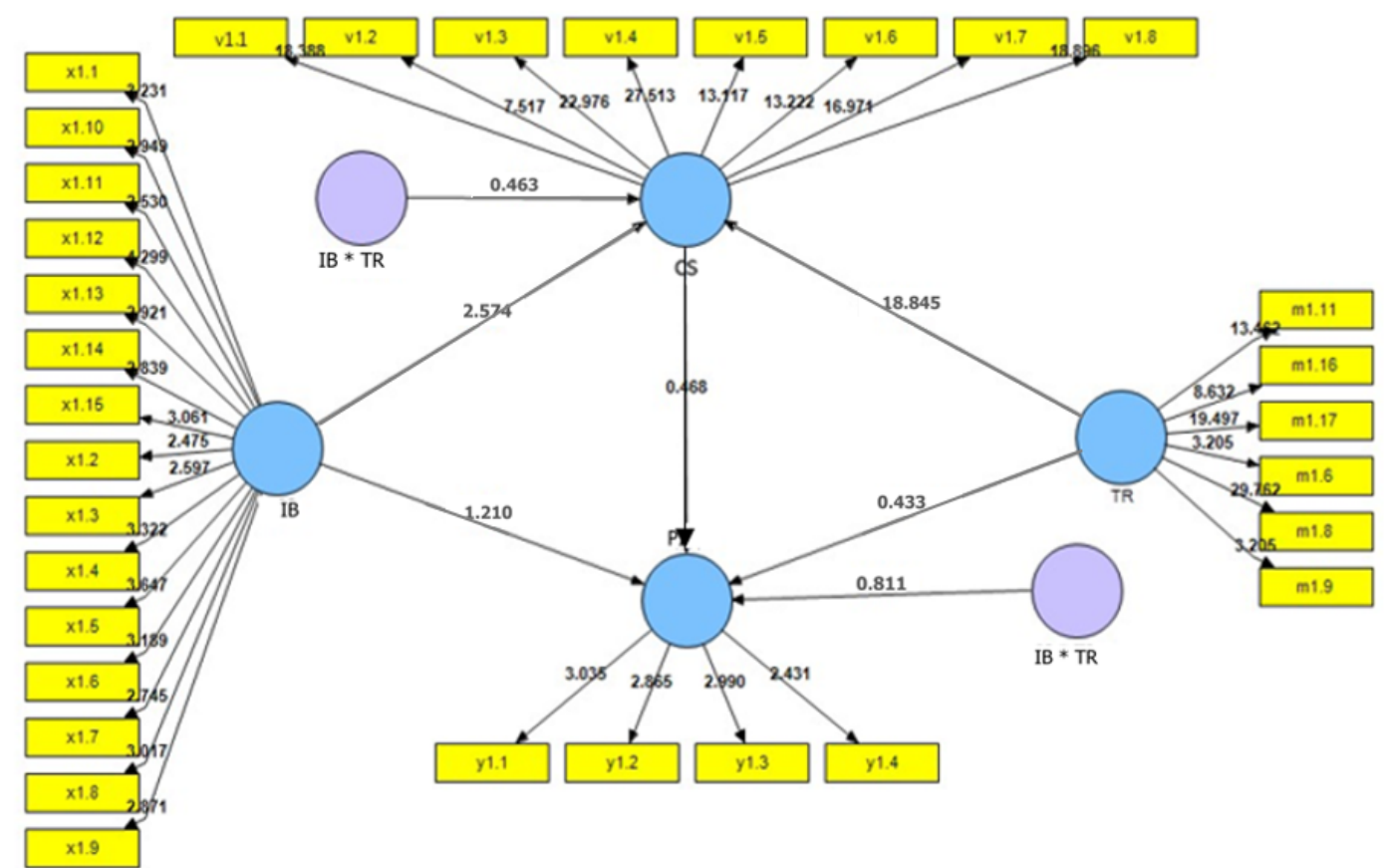

Gambar 4.1. Hasil Output Bootstrapping

Jika t-value lebih besar daripada tabel maka keputusannya adalah menolak $\mathrm{H}_{0}$ dan menerima $\mathrm{H}_{\mathrm{a}}$ (alternatif). Secara umum, model struktural berdasar nilai t-value pada Gambar 4.2 dan berdasarkan nilai-nilai dari koefisien jalur (path coefficient) seperti terlihat pada Tabel 1.

Tabel 1 Path Coefficients (Mean, STDEV, T-Values)

\begin{tabular}{|l|c|c|c|c|c|}
\hline & $\begin{array}{l}\text { Original } \\
\text { Sample } \\
(\mathbf{O})\end{array}$ & $\begin{array}{c}\text { Sample } \\
\text { Mean } \\
(\mathbf{M})\end{array}$ & $\begin{array}{c}\text { Standard } \\
\text { Deviation } \\
(\text { STDEV) }\end{array}$ & $\begin{array}{c}\text { Standar } \\
\text { Error } \\
(\text { STERR) }\end{array}$ & $\begin{array}{c}\text { T- } \\
\text { Statistics }\end{array}$ \\
\hline IB - PI & 0.2217 & 0.1729 & 0.1826 & 0.1826 & 1.2070 \\
\hline IB - CS & -0.2014 & -0.1694 & 0.0869 & 0.0869 & 2.3040 \\
\hline IB* TR - CS & 0.0102 & -0.0014 & 0.0397 & 0.0397 & 0.5013 \\
\hline IB * TR - PI & 0.2818 & 0.2517 & 0.3248 & 0.3248 & 0.8641 \\
\hline CS - PI & 0.2623 & 0.1575 & 0.5622 & 0.5622 & 0.4655 \\
\hline TR - PI & -0.2545 & -0.1297 & 0.6134 & 0.6134 & 0.4130 \\
\hline TR - CS & 1.0470 & 1.0467 & 0.0564 & 0.0564 & 18.5494 \\
\hline
\end{tabular}

Hipotesis 1: konstruk Islamic Branding (IB) dengan Customer Satisfaction (CS), terlihat konstruk Islamic Branding (IB) memberikan pengaruh yang signifikan terhadap konstruk Customer Satisfaction (CS), karena masing-masing nilai t-nya (t-IB-CS) lebih besar dari nilai yang disarankan $(2,3040>1,96)$. Sehingga dapat dikatakan hipotesis diterima, dimana konstruk Islamic Branding (IB) secara signifikan berpengaruh terhadap Customer Satisfaction (CS) nasabah menggunakan jasa perbankan syariah di BMT Kampoeng Syariah.

Hipotesis 2: konstruk Islamic Branding (IB) terhadap Purchase Intention (PI), dapat dikatakan hubungan konstruk Islamic Branding (IB) tidak memberikan pengaruh yang signifikan terhadap konstruk Purchase Intention (PI) karena nilai t-nya (t-IB-PI) lebih kecil dari nilai t-tabel $(1,2070<1,96)$, sehingga hipotesis ditolak, dan dapat dinyatakan 
konstruk Islamic Branding (IB) tidak memberikan pengaruh yang signifikan terhadap konstruk Purchase Intention (PI) untuk menggunakan jasa perbankan syariah di BMT Kampoeng Syariah Medan.

Hipotesis 3: konstruk Customer Satisfaction (CS) terhadap Purchase Intention (PI), dapat dilihat hubungan konstruk Customer Satisfaction (CS) tidak memberikan pengaruh yang signifikan terhadap konstruk Purchase Intention (PI) karena nilai t-nya (t-CS-PI) lebih kecil dari nilai t-tabel $(0,4655<1,96)$; sehingga hipotesis ditolak, dan dapat dinyatakan konstruk Customer Satisfaction (CS) tidak memberikan pengaruh yang signifikan terhadap konstruk Purchase Intention (PI) untuk menggunakan jasa perbankan syariah di BMT Kampoeng Syariah Medan.

Hipotesis 4: konstruk Islamic Branding (IB) terhadap Purchase Intention (PI) dengan konstruk Customer Satisfaction (CS) sebagai variabel intervening, disini hubungan antara konstruk Islamic Branding (IB) terhadap konstruk Purchase Intention (PI) menggunakan jasa perbankan Syariah dengan konstruk Customer Satisfaction (CS) sebagai variabel intervening merupakan pengaruh tidak langsung variabel Islamic Branding (IB) terhadap Purchase Intention (PI) melalui Customer Satisfaction (CS) nasabah. Pengujian pengaruh mediasi ini dilakukan dengan menggunakan rumus Sobel.

Besarnya koefisien tidak langsung Islamic Branding (IB) terhadap Purchase Intention (PI) merupakan perkalian dari pengaruh variabel Islamic Branding (IB) terhadap variabel Customer Satisfaction (CS) nasabah dengan variabel Customer Satisfaction (CS) nasabah terhadap Purchase Intention (PI) nasabah, sehingga didapatkan nilai t-hitung (t-IB*CSPI) sebesar 0,4103. Karena nilai t-nya lebih kecil dari nilai t-tabel $(0,4103<1,96)$, berarti parameter mediasi tersebut tidak signifikan. Maka dengan demikian model pengaruh tidak langsung dari variable Islamic Branding (IB) terhadap Purchase Intention (PI) melalui Customer Satisfaction (CS) nasabah ditolak. Oleh karena itu, Islamic Branding (IB) tidak terdapat pengaruh yang signifikan terhadap Purchase Intention (PI) menggunakan jasa perbankan Syariah di BMT Kampoeng Syariah Medan dengan melalui Customer Satisfaction (CS) nasabah sebagai variabel intervening.

Hipotesis 5: konstruk Islamic Branding (IB) terhadap Customer Satisfaction (CS) dengan konstruk Tingkat Religiusitas (TR) sebagai variabel moderator. Hubungan konstruk Islamic Branding (IB) terhadap Customer Satisfaction (CS) dengan Tingkat Religiusitas sebagai variabel moderator merupakan hubungan dengan pengaruh mediasi yakni perkalian antara variabel moderator Tingkat Religiusitas dengan variabel predictor Islamic Branding terhadap Customer Satisfaction (CS). Hasil pengolahan data hubungan Islamic Branding (IB) terhadap Customer Satisfaction (CS) dengan Tingkat Religiusitas sebagai variabel moderator (M) adalah tidak signifikan. Berdasarkan tabel di atas diperoleh t-hitung (t-IB*TR-CS) sebesar 0,5013. Karena t-hitung lebih kecil dari t-tabel $(0,5013<1,96)$, maka hipotesis ditolak. Oleh karena itu, Islamic Branding (IB) tidak berpengaruh secara signifikan terhadap Customer Satisfaction (CS) dengan Tingkat Religiusitas sebagai variabel moderator (M1) dalam menggunakan jasa perbankan syariah di BMT Kampoeng Syariah Medan.

Hipotesis 6: Konstruk Islamic Branding (IB) terhadap Purchase Intention (PI) dengan konstruk Tingkat Religiusitas (TR) sebagai variabel moderator. Hubungan Islamic Branding (IB) terhadap Purchase Intention (PI) dengan Tingkat Religiusitas (TR) sebagai variabel moderator merupakan hubungan dengan pengaruh mediasi (moderating effect) yakni perkalian antara variabel moderator Tingkat Religiusitas dengan variabel prediktor Islamic Branding (IB) terhadap Purchase Intention (PI). Hasil pengolahan data hubungan Islamic Branding (IB) terhadap Purchase Intention (PI) dengan Tingkat Religiusitas (TR) 
sebagai variabel moderator adalah tidak signifikan. Berdasarkan tabel di atas diperoleh thitung (tIB*TR-PI) sebesar 0,8641. Karena t-hitung lebih kecil dari t-tabel $(0,8641<$ 1,96), maka hipotesis ditolak. Oleh karena itu, Islamic Branding (IB) tidak berpengaruh secara signifikan terhadap Purchase Intention (PI) dengan Tingkat Religiusitas (TR) sebagai variabel moderator dalam menggunakan jasa perbankan syariah di BMT Kampoeng Syariah Medan.

Untuk pengaruh positif dan negatif antar konstruk dapat dilihat berdasarkan nilai-nilai dari koefisien jalur (path coefficient) seperti terlihat pada Tabel 1.

Koefisien parameter untuk variabel konstruk Islamic Branding (IB) pada original sample adalah sebesar 0,2217 . Hal ini menjelaskan bahwa terdapat pengaruh positif pada variabel konstruk Purchase Intention (PI) namun tidak terlihat berpengaruh secara nyata karena nilai t-statistik sebesar 1,2070 atau lebih kecil dari t-tabel $(1,2070<1,96)$. Hal ini juga bisa dijelaskan bahwa sebenarnya penggunaan Islamic Branding berpengaruh terhadap Purchase Intention nasabah namun tidak dapat berpengaruh signifikan karena terdapat variable lain yang lebih besar pengaruhnya, sehingga membuat pengaruh positif Islamic Branding terhadap Purchase Intention menjadi tidak terlihat dimata nasabah.

Koefisien parameter untuk variabel konstruk Islamic Branding (IB) pada original sample adalah sebesar -0,2014. Hal ini menjelaskan bahwa terdapat pengaruh negatif pada variabel konstruk Customer Satisfaction (CS) dan terlihat berpengaruh secara nyata karena nilai t-statistik sebesar 2,3040 atau lebih besar dari t-tabel $(2,3040>1,96)$. Hal ini juga bisa dijelaskan jika terdapat kekecewaan nasabah mengenai harapan mereka dengan penggunaan Islamic Branding, seperti keraguan terhadap kepatuhan atas ketentuan syariah dalam layanan perbankan yang ditawarkan. Keraguan atau belum yakinnya nasabah atas kepatuhan terhadap aturan syariah ini tentunya akan menurunkan Customer Satisfaction.

Koefisien parameter untuk variabel konstruk Islamic Branding (IB) pada original sample adalah sebesar 0,0102. Hal ini menjelaskan bahwa terdapat pengaruh positif pada variabel konstruk Customer Satisfaction (CS) dengan adanya variable moderator Tingkat Religiusitas, namun tidak berpengaruh secara nyata karena nilai t-statistik sebesar 0,5013 atau lebih kecil dari t-tabel $(0,5013<1,96)$. Keberadaan variabel moderator meningkatkan pengaruh Islamic Branding terhadap konstruk Customer Satisfaction dari negative menjadi positif, namun juga membuat pengaruhnya Islamic Branding menjadi tidak signifikan lagi berpengaruh terhadap Customer Satisfaction. Hal ini dapat diartikan pengaruh positif Tingkat Religiusitas nasabah membuat nasabah lebih bisa menerima dan lebih netral sehinggaun Customer Satisfaction yang dirasakan dari pengaruh Islamic Branding semakin kecil dibanding pengaruh variable lainnya.

Koefisien parameter untuk variabel konstruk Islamic Branding (IB) pada original sample adalah sebesar 0,2818. Hal ini menjelaskan bahwa terdapat pengaruh positif pada variabel konstruk Purchase Intention (PI) dengan adanya variable moderator Tingkat Religiusitas, namun tidak berpengaruh secara nyata karena nilai t-statistik sebesar 0,8641 atau lebih kecil dari t-tabel $(0,8641<1,96)$. Dapat dilihat disini dengan adanya variable maderator Tingkat Religiusitas sedikit menambah pengaruh positif Islamic Branding terhadap Purchase Intention. Sama halnya disini juga dapat diartikan pengaruh positif Tingkat Religiusitas nasabah membuat nasabah lebih bisa menerima dan lebih netral sehingga pengaruh untuk konstruk Purchase Intention (PI) dari penggunaan Islamic Branding (IB) semakin kecil dibanding pengaruh variable lainnya.

Koefisien parameter untuk variabel konstruk Customer Satisfaction (CS) pada original sample adalah sebesar 0,2623 . Hal ini menjelaskan bahwa terdapat pengaruh positif pada 
variabel konstruk Purchase Intention (PI), namun tidak berpengaruh secara nyata karena nilai t-statistik $=0,4655$ atau lebih kecil dari t-tabel $(0,4655<1,96)$. Dapat dikatakan konstruk Customer Satisfaction tidak menjadi variable yang berpengaruh nyata dalam Purchase Intention nasabah, hal ini dapat dijelaskan bahwa nasabah BMT yang beragama Islam tidak mendapatkan Customer Satisfaction yang dapat mempengaruhinya untuk meningkatkan atau setidaknya memiliki Purchase Intention (PI).

Koefisien parameter untuk variabel konstruk Tingkat Religiusitas (TR) pada original sample adalah sebesar $-0,2545$. Hal ini menjelaskan bahwa terdapat pengaruh negatif pada variabel konstruk Purchase Intention (PI), namun tidak berpengaruh secara nyata karena nilai t-statistik=0,4130 atau lebih kecil dari t-tabel $(0,4130<1,96)$. Sama halnya disini juga dapat diartikan walaupun mempunyai pengaruh negative, Tingkat Religiusitas nasabah membuat nasabah lebih bisa menerima dan lebih netral sehingga pengaruh untuk konstruk Purchase Intention (PI) kecil dianggap tidak berpengaruh secara nyata.

Koefisien parameter untuk variabel konstruk Tingkat Religiusitas (TR) pada original sample adalah sebesar 1,0470. Hal ini menjelaskan bahwa terdapat pengaruh positif terbesar (dari variable lain yang diteliti dalam penelitian ini) pada variabel konstruk Customer Satisfaction (CS), dan berpengaruh secara nyata karena nilai tstatistik=18,5494 atau lebih besar dari t-tabel $(18,5494>1,96)$. Maka dapat disimpulkan disini variable yang paling mempengaruhi Customer Satisfaction adalah variable Tingkat Religiusitas. Hal ini dapat terjadi karena umumnya nasabah yang memiliki Tingkat Religiusitas yang baik menginginkan mendapatkan Customer Satisfaction menjadi nasabah perbankan syariah sesuai keyakinan dan kepatuhannya pada hukum syariah.

Berdasarkan hasil pembahasan diatas, maka dapat dikatakan bahwa tidak ada variable yang diteliti dalam penelitian ini yang signifikan berpengaruh terhadap Purchase Intention. Tentu merupakan suatu ironi, karena variable-varibel yang diteliti dalam penelitian ini sebenarnya diharapkan menjadi variabel yang dapat diandalkan berpengaruh signifikan dalam meningkatkan Purchase Intention.

Untuk meningkatkan Purchase Intention (PI) maka perlu dibuat strategi agar variabelvariabel tersebut dapat meningkat menjadi berpengaruh positif dan signifikan terhadap Purchase Intention. Pertama harus diperhatikan variable konstruk yang memiliki pengaruh signifikan terbesar, yaitu dalam penelitian ini adalah variable Islamic Branding. Variabel inilah yang paling berpengaruh walaupun belum signifikan terhadap Purchase Intention. Harus dikaji faktor apa termasuk dalam variabel ini yang membuat variabel Islamic Branding ini menjadi tidak bisa berpengaruh positif dan signifikan terhadap Purchase Intention.

Terlihat variabel Islamic Branding mempunyai pengaruh negative terbesar terhadap Customer Satisfaction. Variabel Customer Satisfaction memiliki pengaruh positif terbesar terhadap Purchase Intention. Dan variabel Customer Satisfaction mendapatkan pengaruh positif paling besar dan signifikan dari variabel Tingkat Religiusitas.

Kita dapat mencari factor apa diantara tiga faktor Islamic branding (Alserhan, 2010); yaitu Islamic brand by compliance, Islamic brand by origin dan Islamic brand by customer; yang memiliki keterkaitan erat terhadap Customer satisfaction dan variabel Tingkat Religiusitas. Faktor Islamic Brand by Compliance merupakan faktor yang memiliki keterkaitan paling erat terhadap Customer satisfaction dan variabel Tingkat Religiusitas.

Untuk membenahi factor Islamic Branding by Compliance, maka Islamic brand harus menunjukkan dan memiliki daya tarik yang kuat pada konsumen dengan cara patuh dan taat kepada syariah Islam (Jumani, et. al, 2012). 
Dengan kesungguhan menunjukkan dan memiliki daya tarik yang kuat pada konsumen dengan cara patuh dan taat kepada syariah Islam, maka diharapkan pengaruh variabel Tingkat Religiusitas akan semakin besar berpengaruh positif signifikan terhadap Customer Satisfaction dan pengaruh Islamic Branding juga bisa menjadi positif dan signifikan terhadap Customer Satisfaction. Kondisi inilah yang diharapkan dapat meningkatkan Purchase Intention secara signifikan, mengingat variabel Customer Satisfaction memiliki pengaruh positif terbesar terhadap Purchase Intention.

\section{KESIMPULAN}

Berdasarkan analisis pembahasan dari hasil penelitian yang telah diuraikan, dapat ditarik kesimpulan dari penelitian, yaitu bahwa diantara variabel yang diteliti dalam penelitian ini, hanya variabel Islamic Branding yang terbukti secara signifikan berpengaruh terhadap Customer Satisfaction nasabah menggunakan jasa perbankan syariah di BMT Kampoeng Syariah Medan. Untuk itu, dalam upaya untuk meningkatkan Purchase Intention (PI) maka perlu dibuat strategi agar variabel-variabel tersebut dapat meningkat menjadi berpengaruh positif dan signifikan terhadap Purchase Intention., yaitu dengan membenahi faktor Islamic Branding by Compliance, dimana Islamic brand harus menunjukkan dan memiliki daya tarik yang kuat pada konsumen dengan cara patuh dan taat kepada syariah Islam.

\section{UCAPAN TERIMA KASIH}

Peneliti mengucapkan terimakasih kepada Direktorat Riset dan Pengabdian Masyarakat Direktorat Jenderal Penguatan Riset dan Pengembangan Kementerian Riset Teknologi dan Pendidikan Tinggi Republik Indonesia (KEMENRISTEKDIKTI) yang telah mendanai penelitian ini.

\section{DAFTAR PUSTAKA}

Alserhan, B. A. (2010). On Islamic branding: Brands as good deeds. Journal of Islamic Marketing, 1(2), 101-106.

El-Menouar, Y. (2014). The Five Dimensions of Muslim Religiosity . Results of an Empirical Study. Method, Data, Analyses, 8(1), 53-78.

Essoo, N., \& Dibb, S. (2004). Religious Influences on Shopping Behaviour: An Exploratory Study. Journal of Marketing Management, 20(7-8), 683-712.

Fatema, M., Foyez Ahamd Bhuiyan, \& Mostaq Ahmad Bhuiyan. (2013). Shari ' a Compliance in Building Identified Islamic Brands. Ejbm, 5(11).

Ferdinand. (2006), Metode Penelitian Manajemen: Pedoman Penelitian untuk skripsi, Tesis dan Disertai Ilmu Manajemen. Semarang: Universitas Diponegoro

Handayani Rinuastuti, B., Darwini, S., Agustiani, E., \& Andilolo, I. R. (2018). Pengaruh Religiusitas Terhadap Perilaku Memilih Bank Syariah Melalui Kepercayaan Merek (Studi Pada Nasabah Bank Syariah di Kota Mataram). Distribusi - Journal of Management and Business, 6(2), 47-60. 
Isa, M., Lubis, H. A., \& Lubis, I. S. (2020). Pengaruh Religiusitas dan Lokasi Terhadap Keputusan Pembelian Konsumen Pada Rahmat Syariah Swalayan City Walk Padangsidimpuan. Jesya (Jurnal Ekonomi \& Ekonomi Syariah), 3(1), 1-15.

Jumani, Zulfikar Ali; Siddiqui, K. (2012). Bases of Islamic Branding in Pakistan : Perceptions or Believes. Interdisciplinary Journal of Contemporary Research in Business, 3(9), 840-848.

Risal, T, \& Alexander, A. (2019). Pengaruh Persepsi Bagi Hasil, Promosi dan Kualitas Pelayanan Terhadap Minat Penggunaan Jasa Perbankan Syariah Tabungan Mudharabah Pada Mahasiswa Universitas Potensi Utama. Jurnal Samudra Ekonomika, 3(2), 118-130.

Risal, Taufiq. (2019a). Pengaruh Kualitas Pelayanan Terhadap Loyalitas Nasabah Dengan Kepuasan Sebagai Variabel Intervening Pada Bmt Kampoeng Syariah. JMB (Jurnal Manajemen Dan Bisnis), $1(1)$. https://doi.org/10.30743/magister.v1i1.1607

Risal, Taufiq. (2019b). Peningkatan peran perbankan syariah dengan menggerakkan sektor riil dalam pembangunan. Accumulated, 1(1), 36-47.

Shah Alam, S., \& Mohamed Sayuti, N. (2011). Applying the Theory of Planned Behavior (TPB) in halal food purchasing. International Journal of Commerce and Management, 21(1), 8-20. https://doi.org/10.1108/10569211111111676

Tjiptono, Fandy. (2014), Pemasaran Jasa - Prinsip, Penerapan, dan Penelitian, Andi Offset, Yogyakarta. 